\title{
CALCULATION OF THE WAVE PARAMETERS FOR SEA DYKE DESIGN AND UPGRADING
}

\author{
Nguyen Manh Hung ${ }^{1}$, Nguyen Khac Nghia ${ }^{2}$, and Duong Cong Dien ${ }^{1}$ \\ ${ }^{1}$ Institute of Mechanics, Hanoi, Vietnam \\ ${ }^{2}$ Center for Estuary and Coastal Engineering (CECE), Hanoi, Vietnam
}

\begin{abstract}
Sea dyke system is the effective mean for protecting the coastal low-lying areas from storm attack (the most dangerous storm induced phenomena are storm wave and surges). The coastal zone of Vietnam is blessed with wide variety of natural resources but at the same time, it is also a highly storm hazard-prone region. The storm number 7 (DAMREY) arrived in the East Sea from $26^{t h}$ to $28^{t h}$ of September 2005 and hit the south part of Red river delta coastal zone and caused sea dykes breaches at some stretches along the sea dyke system of the Nam Dinh province and big property damages of the local communes. In order to cope with the storm activity which is reinforced in the future by climate change, a Science Technology program on the sea dyke upgrading from Quang Ninh to Quang Nam provided by the Ministry of Agriculture and Rural Development has been implemented from April 2007. One of the program's project is "Determining the wave heights for sea dyke designed along the coastal line from Quang Ninh to Quang Nam" with the object to propose a method for the calculation of the wave parameters with appropriate accuracy, simple for used and suitable for the natural condition of the different sectors of coastal line of Viet Nam from Quang Ninh to Quang Nam provinces and to upgrade and fulfill the wave calculation guideline for sea dyke design and upgrading. In the paper, the authors present the results of the project concerning the input data, wave models and the calculated wave parameters with different returning periods for 5 sectors along the coastal line from Quang Ninh to Quang Nam. The obtained results afford the promising of using in the sea dyke design and upgrading.
\end{abstract}

\section{INTRODUCTION}

At present there is a guideline for sea dyke design (14TCN 130-2002) but there are many difficulties for using it and many things have changed during the time including the new sources of wave data especially during the severe weather conditions of monsoons and storms, the development of wave models etc. To overcome the disadvantages of the guideline, the proposed wave computation methods will be based on following steps:

- Calculation of the deep sea waves by the state of the art wave models to obtain the wave parameters with different returning periods $(1 \% \ldots 10 \%)$. The wind input data set has end longed to at least about 20 years to guaranty the reliability of the statistical climatic regime. This data set is obtained from JMA (the wind archives for storms are from the years of 1960 up to now). 
The wave calculations according to the guide line 14TCN 130-2002 will be based on the obtained deep sea waves and the specific bathymetric and coastal line configurations of the 5 sectors from Quang Ninh to Quang Nam. Verifications for all 5 sectors have been executed based on the near shore wave data.

For each sectors the sea dyke designed wave parameters will be calculated as a table of wave parameters with different returning periods along a $20 \mathrm{~km}$ spacing profiles perpendicular to the coastal line. The wave computation will include the effects of astronomical tide, storm surges and wave setup. Thus, the wave calculation procedure is as follows:

- To collect storm and wind data for the research area from Quang Ninh to Quang Nam provinces;

- To set up wave models, model calibration and verification;

- To calculate maximum deep sea storm waves for 5 sectors from Quang Ninh to Quang Nam provinces;

- To calculate the wave parameters with different returning period by using the climatic distribution of wave parameter in the sea and

- To perform the wave propagation from the open sea boundaries to the sea dyke foot for all sectors.

\section{INPUT DATA AND WAVE MODELS}

\subsection{Storm data}

All the storms affected the study zone, the storm parameters (storm center pressures, the maximum wind radii, the maximum wind velocities, the moving speeds and directions of the storms) have been collected. In order to calculate the storm wave the storm wind were retrieved for all the collected storms using the holland's analytic model of the wind and pressure profiles in storms [1]. The number of the collected storms is depicted in the table 1.

\subsection{Wave models and validations}

As the third generation wave model, SWAN is characterized by the crucial role of the nonlinear wave-wave interaction (which is predominated in the storm areas) and the freedom from any a priori constraints imposed on the spectral form during the process of wave evolution while the later condition is not fulfilled in the first and second generation models. The last versions of the model have been improved as the deep water alone wave model and with the including of diffraction of coastal construction (version 40.41, 2005) $[4]$.

The grid for storm wave modeling is $0.25^{0}$ latitude and $0.25^{0}$ longitude with the integration domain extending from $-1^{0} \mathrm{~N}$ to $23^{0} \mathrm{~N}$ and $99^{0} \mathrm{E}$ to $119^{0} \mathrm{E}(97 \times 81$ grid points according to latitude and longitude respectively). Depths were developed from Vietnam Navy maps of the East Sea and neighbor seas with the accuracy of $0.1 \mathrm{~m}$. The wave spectrum is discretized by 40 frequencies that are logarithmically spaced from $0.0459 \mathrm{~Hz}$ to $1.0 \mathrm{~Hz}$ at intervals of $\Delta f / f=0.1$. The wave propagation directions are 72 with the span of $360^{0}$ in $5^{0}$ increments. The maximum number of iterations is 15 for one and three hours computation steps with non-stationary modes. The storm retrieved winds were used as forcing fields is the sea water surface. Although in the SWAN model there is an option 
Table 1. The collected storm from 1945 to 2007 for the deep sea areas of the study zone

\begin{tabular}{|l|c|c|c|}
\hline \multirow{2}{*}{ Sectors } & \multicolumn{2}{|c|}{ Latitudinal boundaries } & $\begin{array}{c}\text { Number of } \\
\text { the storms }\end{array}$ \\
\cline { 2 - 3 } & South latitude & North latitude & 41 \\
\hline Quang Ninh - Hai Phong & $20 . .^{0} 00$ & $21 .^{0} 45$ & 35 \\
\hline Hai Phong - Ninh Binh & $19 .^{0} 00$ & $20 .^{0} 00$ & 38 \\
\hline Thanh - Nghe - Tinh & $18 . .^{0} 00$ & $19 .^{0} 00$ & 21 \\
\hline Binh - Tri - Thien & $17 . .^{0} 00$ & $18 .^{0} 00$ & 8 \\
\hline Quang Nam - Da Nang & $16 .^{0} 00$ & $17 . .^{0} 00$ & 143 \\
\hline Total
\end{tabular}

for interpolation of the wind input fields between two interval wind data but it is not adequate for the wind distribution in the storm center, a special interpolation method has been used for the case.

The initial spectra were computed from the local wind velocities, using the deepwater growth curve of Kahma and Calkoen 1992, cut off at values of significant wave height and peak frequency from Pierson and Moskowitz 1964 [2]. In the computation grid, there are two open geographic boundaries as Taiwan and Bashi straits. In order to give the incoming wave energy along these straits at each computation steps, the wave parameters for each incoming direction coincided with wind direction, were computed from the fetches and wind velocities by the same methods as for the initial conditions. The boundary conditions of the straits Taiwan and Bashi were obtained before SWAN running and have been stored in the specific files.

The SWAN has been calibrated by the wave data collected at the VietsovPetro oil platform MSP1 $\left(107.98^{0} \mathrm{E}, 9.77^{0} \mathrm{~N}\right)$ during the passage of the Muifa (storm number four in Vietnam ranking for the year 2004). By varying some of the physical processes formulations of Janssen and Komen, the most important coefficients for accurate model calibration were determined. While the sensitivity of the model not depends so much on friction coefficients of wind wave or swell, formulations for energy dissipation due to white capping play important role on modeling wave height. In the Komen formulation, the effect of this energy dissipation is greater than the Janssen formulation so it was chosen for further evaluation. The better agreement with the field measurement at MSP1 is the SWAN run with the double decreased of the default coefficient of energy dissipation $(C D S 2=0.000236)[2]$.

With the new coefficient, the SWAN model has been executed for some storms affected the studied area for verification. Two of these storms are shown in detail as below:

\section{Computation of storm waves in storm Frankie (07/1996)}

Frankie was in the north of East Sea from $20^{\text {th }}$ to $22^{\text {nd }}$ July 1996, and then the storm increased its strength and hit the Red river delta on $23^{\text {rd }}$ July with the maximum sustained wind speed of $42 \mathrm{~m} / \mathrm{s}$. The storm caused heavy rain and devastated the coastal zone of the north of Vietnam resulted to 40 depth and more than 200 injuries in human lives. During this time the buoy station of Marine Hydrometeorological Center was exploited in the south of the gulf of Tonkin $\left(18.490^{\circ} \mathrm{N}, 105,840^{\circ} \mathrm{E}\right)$ rather far from the storm center 
so the maximum recorded wave height was not very high. The Fig. 1 depicts the Frankie path and the position of the buoy station on the left and the comparison of the recorded and computed wave heights during the passage of Frankie on the right.

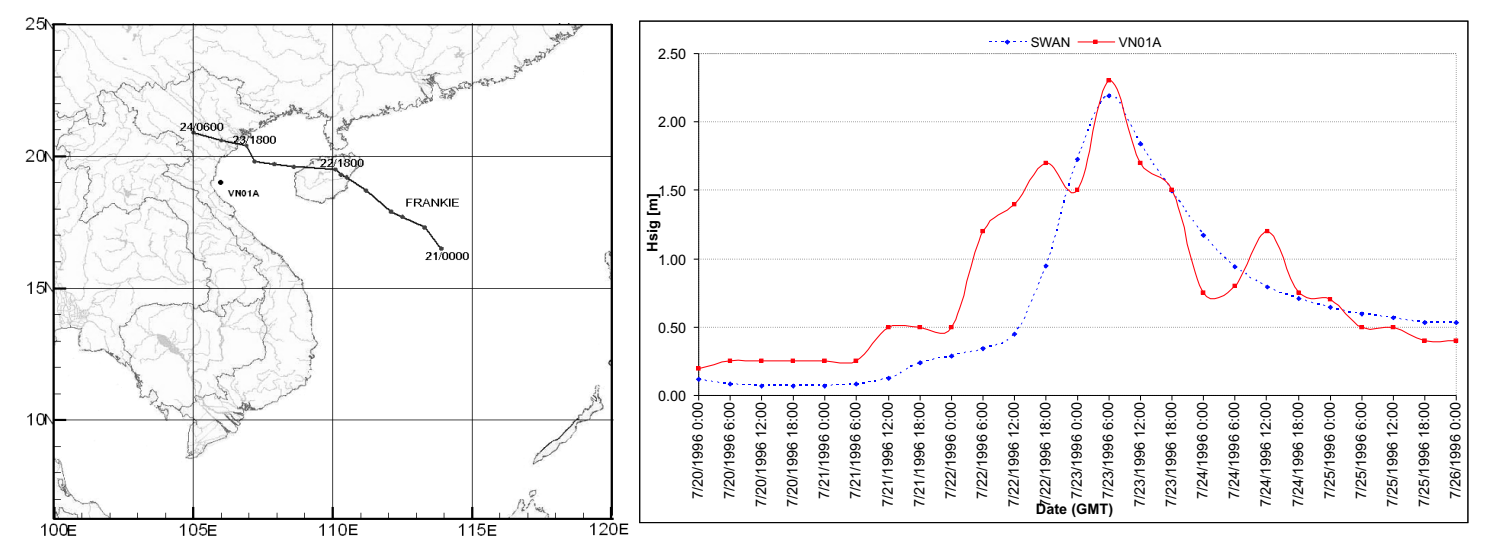

Fig. 1. Frankie's path with the position of the buoy VN01A, a comparison of recoded and computed storm wave heights

Computation of storm waves in storm Wukong (09/2000)

Storm Wukong was first declared in the north of the East Sea on $4^{\text {th }}$ September 2000. After passing the Hainam Island the storm decreased the strength and hit Nghe An province of Vietnam. During the time, the buoy 4001 was operated in the coastal zone of the Quang Tri province quite near the maximum wind zone of the storm and recorded wave heights are rather high. Similar to the Fig. 1, the storm path, buoy's position and the comparison of recorded and computed wave heights are shown in the Fig. 2.
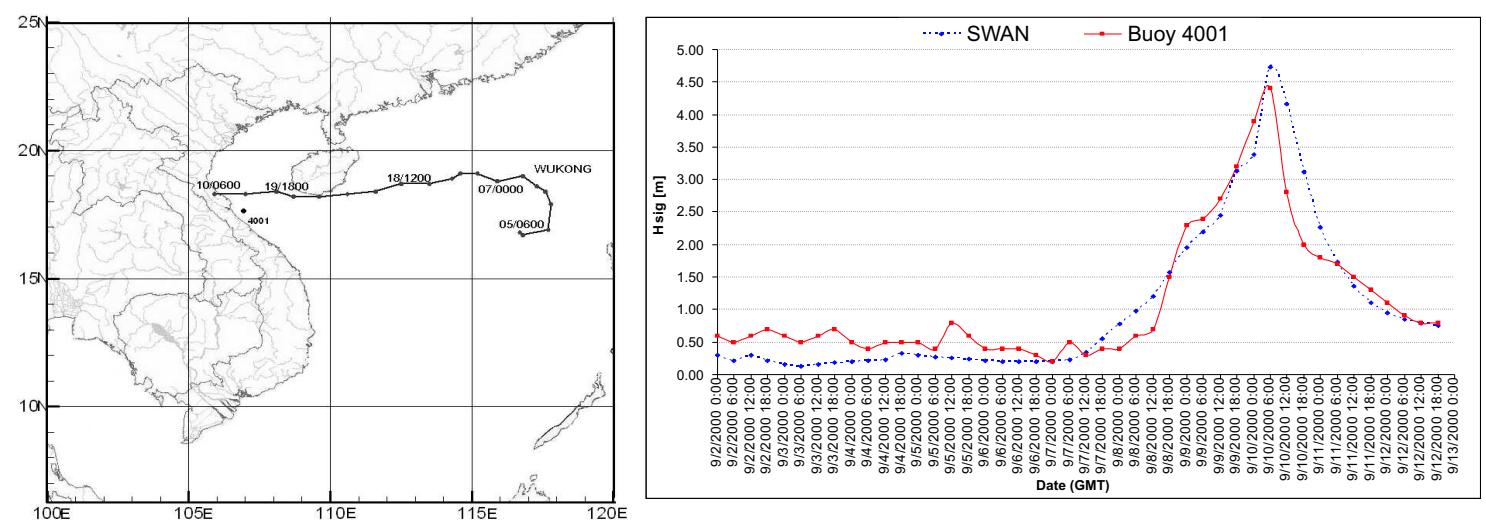

Fig. 2. Wukong's path with the position of the buoy 4001, a comparison of recoded and computed storm waves 
In order to have the quantitative assessments, the values of bias (BIAS) and roof mean square (RMS) have been used to analyze the data set of measurement and computation wave heights of the storms as follows:

$$
\begin{aligned}
& B I A S=\frac{1}{N} \sum\left(\text { Hcom }_{i}-\text { Hobs }_{i}\right), \\
& R M S=\left\{\frac{1}{N} \sum\left(\text { Hcom }_{i}-\text { Hobs }_{i}\right)^{2}\right\}^{1 / 2},
\end{aligned}
$$

where: $N$ - Number of the wave heights (i), H $\operatorname{com}_{i}$ - computed wave heights, $\mathrm{Hobs}_{i}-$ recorded wave heights.

The averaged obtained values of BIAS and RMS in all the cases of storms and monsoons were about \pm 0.05 and 0.25 respectively which are considered rather good fitted between measurements and calculations.

\section{COMPUTATIONS OF DEEP SEA WAVE PARAMETERS}

Because the wave model is very time consuming computation especially for storm wave, parralel to the model, the maximum wave heights and periods in the stroms were calculated by the SMB method [3]. In the results all maximum wave parameters for 143 storms are obtained. Thus, by the end of the computation the maximum wave parameters at each 5 sectors are determined with the returning period of 61 years (the collecting year from 1945 to 2007).

From the experimental analysis, it is known that wave heights considered as random variables, follow a Weibull distribution:

$$
\ln P(>H s)=-\frac{H s}{a}
$$

The undetermined coefficient "a" is easily found from a sequence of a variable Hs values. For the wave periods the probability of exceedence of that once during $\mathrm{N}$ consecutive years is:

$$
\ln P(>H s)=-\frac{H s}{a} .
$$

Based on the (3) and (4) the maximum deep sea wave heights and periods with different returning periods for 5 sectors are determined in the Table 2.

\section{COMPUTATIONS OF WAVE PARAMETERS AT THE NEAR SHORE AND SEA DYKE FOOT}

For the near shore zones, five sectors have been determined to obtain the detail near shore wave parameters focusing to the sea dyke design (see the table 1). Each sector is devided to $20 \mathrm{~km}$ spacing perdipecular to the shore line profiles with the length of $10 \mathrm{~km}$ seaward geting to the deep of about $30 \mathrm{~m}$. There are total 50 profiles and their coastal line ends are depicted in the Fig. 3. In oder to meet the demand of the sea dyke design, the effects of the astronomical tide, storm surges and wave setup with the same returning period probability are added to the mean sea level. The first two of them are obtain from 
Table 2. The maximum wave parameters with different returning periods for the deep sea sectors of the study zone

\begin{tabular}{|l|l|c|c|c|c|}
\hline \multirow{2}{*}{ Sectors } & \multirow{2}{*}{ Parameters } & \multicolumn{4}{|c|}{ Returning periods } \\
\cline { 3 - 6 } & & 10 years & 25 years & 50 years & 100 years \\
\hline \multirow{2}{*}{ Quang Ninh - Hai Phong } & Hsig $[\mathrm{m}]$ & 10.43 & 11.13 & 11.66 & 12.19 \\
\cline { 2 - 6 } & $\mathrm{T}[\mathrm{s}]$ & 12.3 & 12.8 & 13.2 & 13.5 \\
\hline \multirow{2}{*}{ Hai Phong - Ninh Binh } & Hsig $[\mathrm{m}]$ & 8.67 & 9.25 & 9.68 & 10.12 \\
\cline { 2 - 6 } & $\mathrm{T}[\mathrm{s}]$ & 11.1 & 11.5 & 11.8 & 12.1 \\
\hline \multirow{2}{*}{ Thanh - Nghe - Tinh } & Hsig [m] & 7.78 & 8.30 & 8.70 & 9.09 \\
\cline { 2 - 6 } & $\mathrm{T}[\mathrm{s}]$ & 10.4 & 10.8 & 11.1 & 11.4 \\
\hline \multirow{2}{*}{ Binh - Tri - Thien } & Hsig [m] & 8.75 & 9.34 & 9.78 & 10.23 \\
\cline { 2 - 6 } & $\mathrm{T}[\mathrm{s}]$ & 11.1 & 11.6 & 11.9 & 12.2 \\
\hline \multirow{2}{*}{ Quang Nam - Da Nang } & Hsig $[\mathrm{m}]$ & 10.52 & 11.23 & 11.76 & 12.29 \\
\cline { 2 - 6 } & $\mathrm{T}[\mathrm{s}]$ & 12.4 & 12.9 & 13.2 & 13.6 \\
\hline
\end{tabular}

the project "The computation of the sea water level for sea dyke design" of the Science Technology program on the sea dyke upgrading from Quang Ninh to Quang Nam.

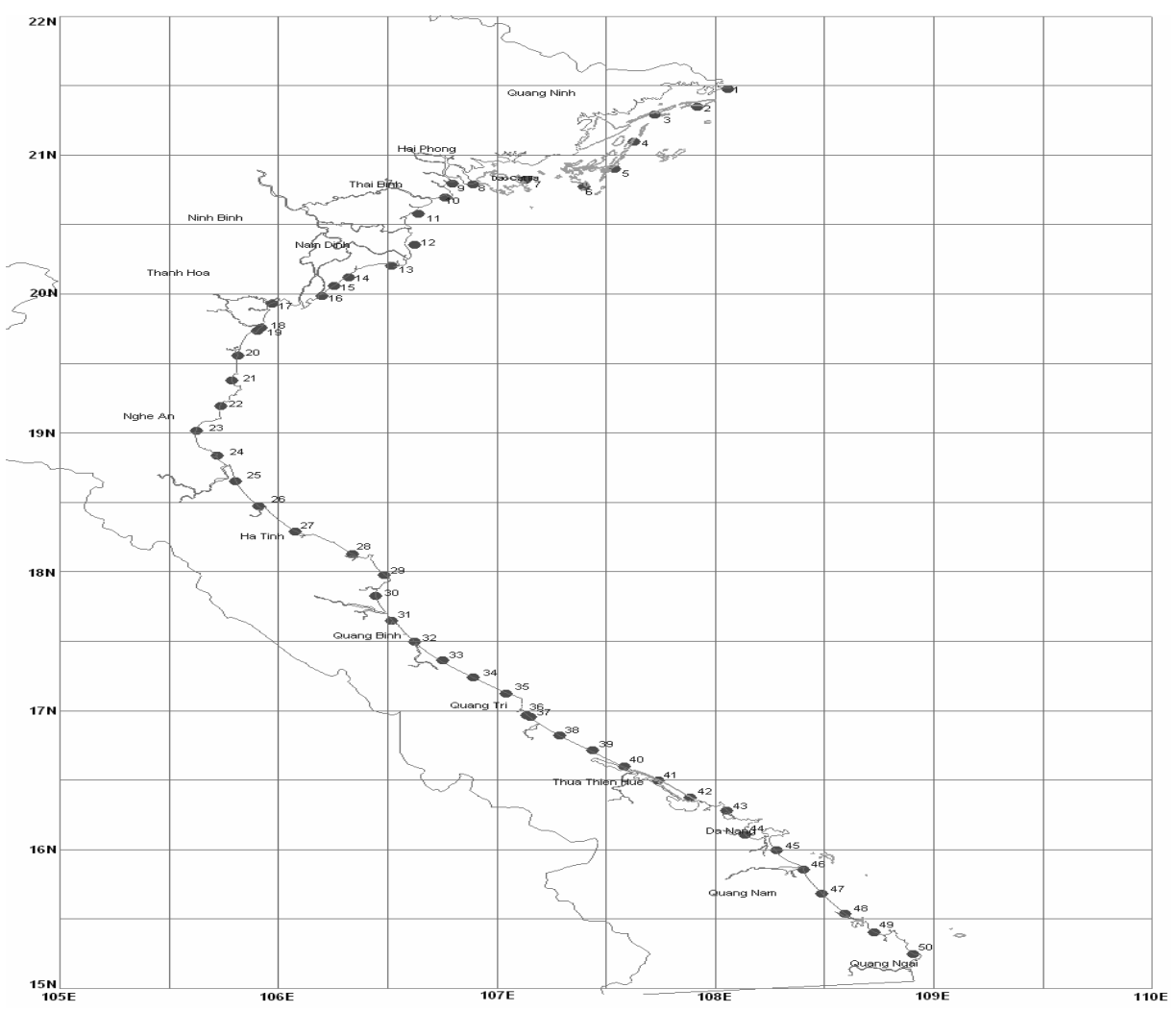

Fig. 3. The positions of the crosshore profiles for wave parameters computations 


\section{- Near shore wave propagation STWAVE 3.0 and SWAN 1-D models}

The STWAVE is used for 2-D wave modeling for 5 sectors to study the wave propagation from the deep sea boundaries to the shore line under the effects of wave refraction, diffraction, shoaling and breaking. The two dimentional wave model also demonstrate the distribution of the near shor wave parameters depending on the near shore bathymetry and coastal line configuration. In oder to study the detail effect of river mouth bathymetry and coastal line to the wave propagation the computation grid for STWAVE simulation is $200 \mathrm{~m} \times 200 \mathrm{~m}$. For the computation of wave parameters along the cross shore profiles, the SWAN 1-D model is used. It can be simulated with different distribution of sea water levels and the more detailed distribution of wave parameters along the profiles will be calculated (for $50 \mathrm{~m}$ spacing from the sea dyke foot). The models have been also verificated with the wave data recorded at the near shore zone of the study area during the monsoon and storm weathers.

\section{- Computation results}

In the figures 4 and 5 the wave heights and directions at the near shore sectors 2 (from Hai Phong to Ninh Binh) and the wave heights along the cross shore profile from the point A to B of the returning period one hundred years are presented. This area of coastal zone is specified with the chronic erosion for near a century and the seadyke system is of paramount important for local people living in the low lying land behind the sea dyke.

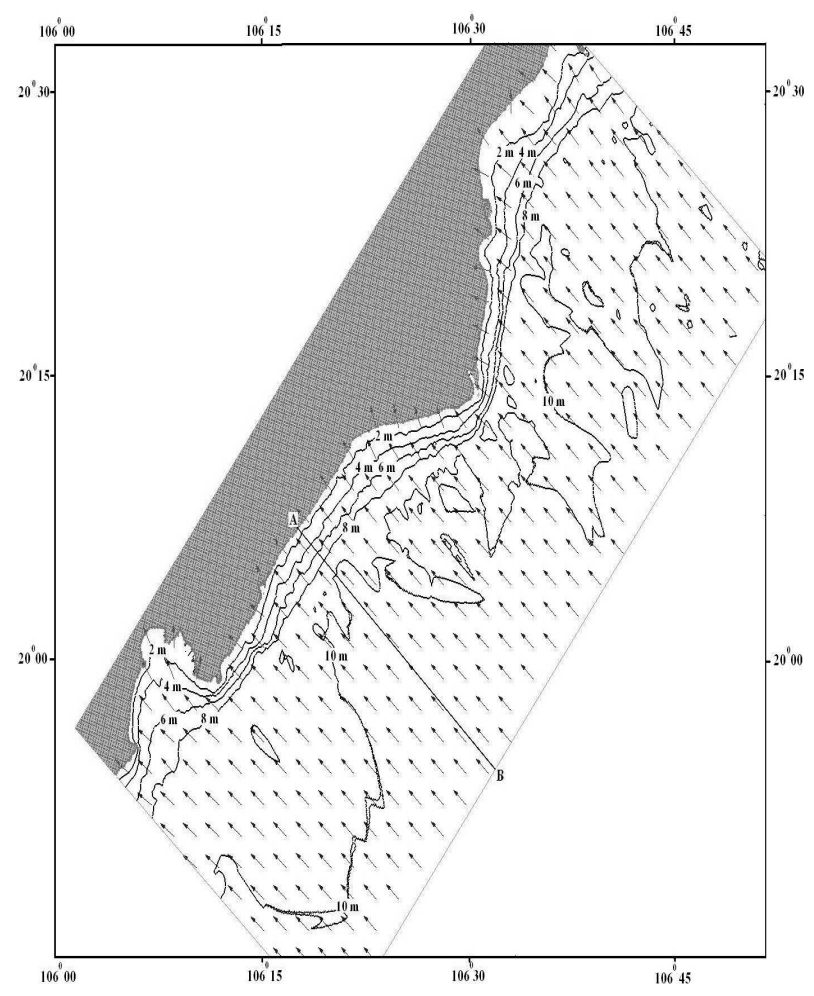

Fig. 4. The wave with returning period one hundred years at Hai Phong - Ninh Binh near shore zone 


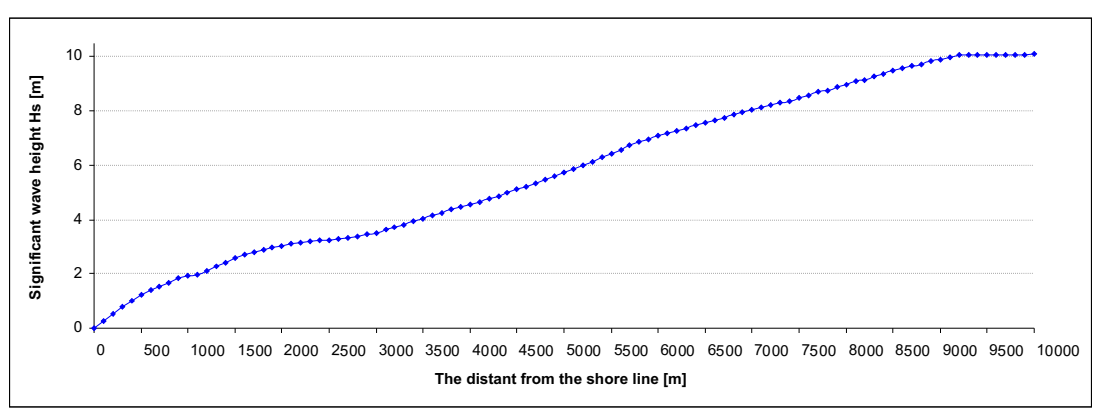

Fig. 5. Cross shore distribution of one hundred years wave heights form the point A to the point B (see the Fig. 4)

In the SWAN-1D simulations the breaking coeficient was accepted as the default value (0.73). The computation results are: significant wave heights (Hs); peak period of the variance density spectrum (RTP); mean absolute wave period (TM01); mean absolute zero-crosing period (TM02) and wave setup. All the above mentioned values are tabulated in tables for each cross-shore profile with the step of $50 \mathrm{~m}$ from the sea dyke foot to 500 $\mathrm{m}$ and $100 \mathrm{~m}$ step futher to the distant $1000 \mathrm{~m}$ seaward. The tables are easy used for the sea dyke designed and construction.

\section{CONCLUSIONS}

In order to meet the need of the adequate wave input parameters at all and to fulfill the research task of the project "Determining the wave heights for sea dyke designed along the coastal line from Quang Ninh to Quang Nam" in particular, the authors have developed the SWAN model for storm and monsoon waves computation in the deep sea areas. For the near-shore zones, 5 sectors are defined and the STWAVE and SWAN-1D models have been executed. The calibrated models were verified in different weather conditions. The final results as the ready wave computed tables for 50 cross shore profiles equally distributed along the shore line from Quang Ninh to Quang Nam provinces are obtained. The results of the project are the amendment of the wave computation guideline for dyke design and the mangrove plantation and constructions for dyke protection meeting to the present accuracy demand in the marine constructions.

This study was funded by the project "Determining the wave heights for sea dyke designed along the coastal line from Quang Ninh to Quang Nam".

\section{REFERENCES}

[1] Gred J. Holland, An analytic model of the wind and pressure profiles in Hurricanes, Monthly Weather Review, Volume 108. Bureau of Meteorology, Department of Science and the Environment, Melbourne, Victoria 3001, Australia, 1212-1218, 1980.

[2] Nguyen Manh Hung, Do Le Thuy, Duong Cong Dien, Storm wave modeling with SWAN, Comparison of measurement data and modeling results for the storm MUIFA 11/2004, Vietnam Journal of Mechanics 27 (2005). 
[3] Nguyen Manh Hung, Duong Cong Dien, Calibration and verification of a storm wave model in the coastal zones of the East Sea, The annual national conference for fluid mechanics 2006, Vung Tau 07/2006

[4] Swan-User Manual, Swan Cycle III version 40.41. Delft University of Technology, 2005

Received May 14, 2009

\section{TÍNH TOÁN CÁC THAM SỐ SÓNG PHỤC VỤ THIẾT KẾ VÀ NÂNG CẤP ĐÊ BIỀN}

Đê biển là hệ thống hữu hiệu để bảo vệ vùng đất trũng ven bờ trong bão (tác động của bão nguy hiểm nhất là gây ra sóng và nước dâng trong bão). Vùng ven bờ của Việt nam được thiên nhiên ban cho các nguồn lợi tự nhiên phong phú nhưng đồng thời cũng là nơi có hiểm họa thiên tai cao. Bão số 7 (DAMREY) xuất hiện trên vùng Biển Đông ngày 26 đến 28 tháng 9 năm 2005 và sau đó đổ bộ vào khu vực phía nam châu thổ sông Hồng gây ra nhiều đoạn đê bị vỡ dọc theo tuyến đê tỉnh Nam Định và gây thiệt hại lớn về của cải của nhân dân địa phương. Để đối phó với hoạt động của bão mà trong tương lai sẽ mạnh lên do biến đổi khí hậu, một Chương trình Khoa học Công nghệ của Bộ Nông nghiệp và Phát triển Nông thôn đã được thực hiện từ tháng 4/2007. Đề tài "xác định chiều cao sóng trong tính toán thiết kế đê biển từ Quảng Ninh đến Quảng Nam" thuộc chương trình nêu trên với mục tiêu là đưa ra các tham số sóng phục vụ thiết kế đê biển có độ chính xác chấp nhận, phù hợp với các điều kiện tự nhiên của khu vực nghiên cứu và đơn giản trong sử dụng. Trong bài báo này, các tác giả đưa ra kết quả thực hiện đề tài, liên quan đến các số liệu đầu vào, mô hình tính sóng và các tham số sóng tính toán được với các chu kỳ lặp khác nhau cho 5 vùng dọc theo bờ biển từ Quảng Ninh đến Quảng Nam. Các kết quả nhận được sẽ được áp dụng trong thiết kế và nâng cấp đê biển. 